УДК 544.77.032.1

\title{
POLARIZABLE FORCE FIELD FOR MOLECULAR DYNAMICS SIMULATIONS OF SILVER NANOPARTICLES
}

\author{
M.M. Blazhynska, ${ }^{*}$, A.V. Kyrychenko*,b, O.N. Kalugin ${ }^{*}, \mathrm{c}$ \\ * V.N. Karazin Kharkiv National University, School of Chemistry, 4 Svobody sqr., 61022 Kharkiv, \\ Ukraine
}

a) $\square$ blazhynska@gmail.com, 는tps://orcid.org/0000-0003-0749-8772

b) $\square$ a.v.kyrychenko@karazin.ua, (1) https://orcid.org/0000-0002-6223-0990

c)》 onkalugin@gmail.com, 1 https://orcid.org/0000-0003-3273-9259

Contact of silver metal surfaces with water, ions and organic ligands experiences induced charges, leading to attractive polarization. These forces play an important role at inorganic/organic interfaces and complement other non-bonded surface interactions. Despite the importance of these interactions, it, however, remains difficult to implement polarization effects to classical molecular dynamics (MD) simulations. In this contribution, we first present an overview of two popular polarizable models, such as Drude oscillator and the rigid rod model, which are utilized to mimic the polarizability of bulk metals. Second, we implemented the rigid rod model to the polarizable force field (FF) for a silver atom, which was further adapted for atomistic MD simulations of silver nanoparticles (AgNPs) composed of 1397 atoms. In our model, induced charge polarization is represented by the displacement of a charge-carrying virtual site attached rigidly to an original $\mathrm{Ag}$ atom. To explore the role of polarization, we compared the performance of the classical nonpolarizable FF and the new polarizable model in the MD simulations of adsorption of water and ions onto quasispherical AgNP and the flat crystalline silver surface. The analysis of the radial distribution function of $\mathrm{Ag}-\mathrm{Ag}$ atoms demonstrated that the introduction of the polarization effect had minor effects on face-centered cubic (fcc) packing of silver atoms of bare and water-solvated AgNPs. We found that the polarizable FF causes some increase in attractive interactions between the silver surface and water molecules and $\mathrm{Na}^{+}$ions. As a crucial test of the developed polarizable model, the structure of adsorbed interfacial water molecules was analyzed. Our data suggest that the environment-induced polarization of the silver surface contributes significantly to the structure of adsorbed interfacial water layers and it also plays an important role in the adsorption of positive ions. However, it was also found out that the polarization effect has a rather short-range effect, so that a minor contribution of silver polarization was seen for adsorption of water molecules and ions from distant solvation shells.

Keywords: silver, nanoparticle, face-centered cubic cell, fcc, polarizable model, Drude oscillator, rigid rod model, molecular dynamics simulations.

\section{Introduction}

Applications of metallic nanoparticles in various chemical, engineering, and medical applications represent one of the most extensively investigated areas of the current materials science [1-4]. Progress in this field requires the development of novel experimental techniques and theoretical approaches. Molecular dynamics (MD) simulation, in partnership with an experiment, has become an essential tool for studying metal nanoparticles at the atomic level [5]. Atomic-scale theoretical methods can provide important insight to the solution-phase synthesis of silver nanostructures that involves the seeded growth [6-7] and the morphological stability [8-9], as well as adsorption of stabilizing agents and solvent molecules onto inorganic metal nanocrystals [10-12]. Numerous MD simulation studies of silver and gold nanoparticles protected by organic ligand monolayers [13-18], synthetic polymers [19-26], and peptides [27-30] have been conducted in the last decade.

Silver metal surfaces in contact with the aqueous environment experience attractive polarization owing to metal-induced charges [31]. This fundamental physical interaction complements Van der Waals surface interactions; however, despite recent progress in this field, it remains difficult to implement polarization effects to classical MD simulations [32]. A much less considered contribution to the binding strength is a polarization of the metal surface through the typically polar and often ionic environment created by solvents, surfactants, peptides or DNA. Therefore, the development of advanced computational models for complex hybrid organic/inorganic nanomaterials is required [33-36]. 
The main goal of our study is the implementation of the polarizable Ag model to the existing nonpolarizable FF, which were recently used for MD simulations of silver nanoparticles and interfaces [8,19,24,37-38]. Besides, the influence of polarization effects on the adsorption of water molecules and ions at the silver/water interface is considered.

\section{Review of Polarizable Force Fields}

Metal surfaces acquire a charge in aqueous systems and these attracted surface ions form a layer balancing the oppositely charged counter ions. This structure is known as the electrochemical double layer (EDL). EDLs profoundly affect the physical and chemical behavior of such heterogeneous systems [39]. Unless there are a lot of common techniques, which involve the measurement of electrokinetic phenomena caused by the tangential movement of an electrolyte fluid relative to the charged surface, the molecular dynamics methods of charged NPs surfaces simulations are only arising. The investigations, which have already found their use in studying these systems, are summarized below.

Iori and Corni have recently introduced novel polarizable MD models for a bulk gold and gold surface (001) and (111) [40]. Their approach is based on the Drude oscillator model [32] in which a virtual interaction site is added to the real metal atom being connected by a harmonic bond with a force constant $k$ and the null rest length $l_{0}=0$ (Fig. 1 left). To keep the system neutral, the authors offered to assign negative charge $-q$ on the real metal atom and positive charge $+q$ placed on the virtual site. The electrostatic interaction between these two charges on the same polarizable metal atom is not included in the energy and force calculations during the simulations. Additionally, a virtual site has no Van der Waals interactions with other atoms. Thus, the Drude oscillator model for metal requires three parameters: a force constant $k$, point charge $q$ and a mass $m$, which help to mimic the behavior of the polarizable metal atom. Their combinations define the quantities that determine the behavior of the polarizable metal atom: the polarizability $\alpha(1)$ and the harmonic oscillator frequency $\omega(2)$ [40], respectively.

$$
\begin{aligned}
& \alpha=\frac{q^{2},}{k}, \\
& \omega=\frac{\sqrt{k}}{m},
\end{aligned}
$$

However, some disadvantage of this model is that the fictitious moving charge can collapse on other charges, which can lead to the system's crash.

Attractive polarization occurs in response to exterior charges in the vicinity of a metal surface and it scales with the magnitude of atomic charges and with the length of multipoles, such as the distance between a real metal atom and a virtual site.

\section{Drude Oscillator Model}
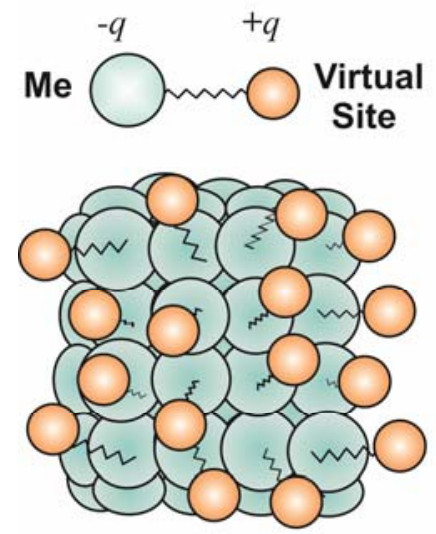

\section{Rigid Rod Model}
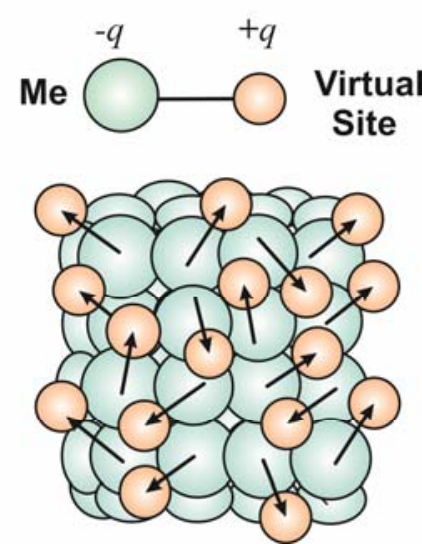

Figure 1. Scheme of the two polarizable FF models for bulk metal $(\mathrm{Me})$. A $M e$ atom is shown as a cyan ball and the virtual site is represented by an orange sphere. Both of them have their charges: $M e$ is charged negatively $(-q)$ and the virtual site is charged positively $(+q)$. On the left side the Drude oscillator model is shown. Metal atom and its virtual site are bonded by a harmonic bond (shown as a staggered line). On the right side the rigid rod model is presented. The Me atoms and its virtual sites have a fixed bond (shown as an arrow). 
Further improvement of the Drude oscillator model was given by the rigid rod model (Fig. 1 right) $[32,40]$. In the rod model, the rod always has a finite dipole moment and there is a fixed distance $l_{0}$ between the real gold atom and a virtual interaction site. Thus, the virtual site is forced to be at a given distance $l_{0}$ from the original metal atom, however, its orientation is still free. Similarly to the Drude oscillator model, the virtual site has no Van der Waals interactions, while it bears a positive charge $q$ ( $-q$ is assigned to the original metal atom) and it has an atomic mass $m$. The rod model also requires three parameters: distance $l_{0}$, partial charge $q$, a mass $m$. Unlike the Drude oscillator model, the rod model always has a finite dipole moment $\mu$ (3). To reproduce the physically meaningful polarizability of bulk metals, this model requires an orientational averaging (i.e., $T>0$ ), so that the relation among the parameters and the characterizing physical quantities involve the temperature: the polarizability is also given by $\alpha$ as defined by (1) $[32,40]$. The typical values of these parameters for gold are $T=300 \mathrm{~K}$, $q=0.3, l_{0}=0.7 \AA$ and $m=0.5$ a.m.u. [40]. This choice was confirmed by the necessity of making stable MD simulations and the fact that the dipole moment of every single rod should average to zero. It was found that $\mathrm{q}=0.3$ gave the sufficient polarizability while not causing the system to freeze [40]. The MD simulations based on the Lennard-Jones 6-12 potential for gold and performed in an NVT ensemble, [40] demonstrated that the rod model is capable to reproduce the interaction energy between a charge and neutral metal slab.

$$
\begin{gathered}
\mu=q l_{0} \\
\bar{\mu}=\frac{\mu^{2}}{3 k_{B} T}=\frac{q^{2} l_{0}^{2}}{3 k_{B} T}
\end{gathered}
$$

The polarizable model for gold, suitable for biomolecular MD simulations, has recently been introduced in the GolP [41] and GolP-CHARMM [42-43] force fields, respectively. Recently, this approach has further been extended and implemented in new FF, AgP-CHARMM [44-46], suitable for simulations of the aqueous $\operatorname{Ag}(111)$ and $\operatorname{Ag}(100)$ interfaces, where abbreviations (111) and (100) refer to the Miller indices form a notation system in crystallography for planes in crystal lattices. AgPCHARMM utilizes the rigid rod model to mimic the polarizability of the Ag atoms, where the total average dipole moment $\mu$, is determined by (4), where $T=300 \mathrm{~K}, q=0.308, l_{0}=0.7 \AA$. Moreover, to ensure atop-site adsorption, both GolP-CHARMM and AgP-CHARMM introduce additional virtual interaction sites, rigidly placed between real metal atoms in crystal slabs, which allow overcoming some problems with the artificial orientation of hydrogen atoms of water molecules. Most recent extension of polarizable FF has been for the aqueous Pd(111) interface, referred to as PdP-CHARMM [47]. Unfortunately, the applicability of all these force fields is limited to specific (111) and (100) surfaces. Therefore, the tedious re-parametrization procedure is required before introducing new parameters for other crystal facets [48]. Therefore, MD simulations of spherical nanoparticles are not straightforward with this force field.

\section{Molecular dynamics simulation setup}

The preformed silver nanoparticles (AgNPs) were approximated by the perfect face-centered cubic ( $f c c$ ) crystalline structure (Fig. 2). Two force-field (FF) models for AgNP were considered: (i) a nonpolarizable model for Ag, consisting of neutral atoms with the zero charge, (ii) a polarizable model for $\mathrm{Ag}$, in which metal polarization was implemented by using the rigid rod approach. In both models, the repulsion and dispersion terms of nonbonded interactions between silver atoms were computed by using the Lennard-Jones 12-6 potential energy function (5), which describes the dependence of the potential interaction energy $V_{L \mathcal{J}}\left(r_{i j}\right)$ of two silver atoms as a function of the interatomic distance. The nonbonded interaction parameters Ag-Ag were based on non-polarizable INTERFACE-FF [31,36,49] and were validated in our recent works $[8,19,24,37]$. For MD simulations in vacuum, no of any rigid bonds and restraints were applied between silver atoms, so that the silver core crystalline structure was maintained by the Ag-Ag nonbonded LJ interactions.

$$
\begin{array}{rl}
V_{L J}\left(r_{i j}\right)=4 \mathcal{E}_{i j}\left(\left(\frac{\sigma_{i j}}{r_{i j}}\right)^{12}-\left(\frac{\sigma_{i j}}{r_{i j}}\right)^{6}\right) & r<r_{\text {cutoff }} \\
V_{L J}\left(r_{i j}\right)=0 & r>r_{\text {cutoff }}
\end{array}
$$


Electrostatic interactions between two charged particles were calculated by the Coulomb potential (6). Therefore, during MD simulations the electrostatic interactions among the polarizable Ag atom dipoles were treated by Coulomb term allowing collective and cooperative motions of dipoles in response to external charges.

$$
V_{c}\left(r_{i j}\right)=\frac{q_{i} q_{j}}{\pi \varepsilon_{0} r_{i j}} \quad r<r_{\text {cutoff }}
$$

The description of the polarizable model for AgNP is represented as follows: Ag atom has $\mathrm{q}=-0.308$, whereas the virtual site has $q=+0.308$ to make the model neutral. An alternative model with positive and negative charges altered between each other was also considered. In the original rigid rod model, the mass of the virtual site has been assigned to zero [40]. In our polarizable model, we assigned the minimal nonzero mass of 1.0, as required in the GROMACS package. The rigid rod was approximated with the rigid chemical bond of $l_{0}=0.07 \mathrm{~nm}$ and $k_{\mathrm{b}}=1 \times 10^{12} \mathrm{~kJ} / \mathrm{mol} \cdot \mathrm{nm}^{2}$, respectively. The initial values of $\mathrm{q}$ and $l_{0}$ were taken from the original study [44]. The nonbonded interaction parameters Ag-Ag $\sigma=0.2964 \mathrm{~nm}$ and $\varepsilon=19.05865 \mathrm{~kJ} / \mathrm{mol}$ were taken from our recent works [9,24]. However, both parameters $\sigma$ and $\varepsilon$ were assigned to zero for the virtual site. For MD simulations of polarizable AgNPs in water, the model was adjusted by adding the LJ interactions between Ag atoms and hydrogen atoms (HW) of SPC waters. The correction LJ interaction parameters Ag-HW were taken [50] as following: $\sigma=0.30584 \mathrm{~nm}$ and $\varepsilon=0.74323 \mathrm{~kJ} / \mathrm{mol}$, respectively.

AgNP was simulated according to the following procedure: (i) Steepest descent energy minimization was performed for 500 steps. (ii) Initial orientation of dipoles and atomic velocities were generated with the Maxwellian distribution at $T=250 \mathrm{~K}$. Productive MD sampling was carried out at the reference temperature of $T=303 \mathrm{~K}$. The water molecules are described by the simple point charge (SPC) model [51]. The parameters for $\mathrm{Na}^{+}$and $\mathrm{Cl}^{-}$ions were used as implemented in the GROMOS $45 \mathrm{a} 3 \mathrm{FF}$ [52]. The reference temperature of $T=303 \mathrm{~K}$, which was kept constant using the Berendsen weak coupling scheme with the temperature coupling constant of $\tau_{T}=0.1 \mathrm{ps}$ [53]. The cutoff distance of $0.8 \mathrm{~nm}$ was used for Lennard-Jones interactions. The MD simulation time step was $2 \mathrm{fs}$ with the neighbor list updates every $10 \mathrm{fs}$. The MD simulations were carried out using the GROMACS set of programs, version 4.6.5 [54]. Molecular graphics and visualization were performed using VMD 1.9.2 [55].

\section{Results and discussion}

\section{Isolated Silver Nanoparticles}

MD simulations of silver nanoparticles of 1397 atoms were carried out by the using of polarizable and nonpolarizable FFs in vacuum. To investigate the accuracy of the nanoparticles' structure (Fig. $2 a$ ) and to compare their behavior, we used the dependences shown below.

Radial Distribution Function. To characterize the structure, atom packing and the long-range order of $\mathrm{Ag}$ atoms in AgNPs, the pair radial distribution function (RDF) $g(r)$ was calculated between all silver atoms. As can be seen in Fig. 2b, the RDF plots of Ag-Ag interactions of both models are characterized by narrow and sharp peaks and have the same peak positions. The sharp RDF peaks are indicative of small-amplitude vibrations of $\mathrm{Ag}$ atoms about the lattice site position and very low diffusive movements over the local region of the crystal. These results demonstrate that the polarizable model represents well quasi-spherical AgNPs with face-centred cubic $f c c$ crystalline structure [56-57].

Root Mean Square Displacements. For further characterization of the dynamic stability of AgNPs, their structures were analyzed by calculating the root mean square displacement $(R M S D)$ of $\mathrm{Ag}$ atoms as a function of time. The RMSD of all $\mathrm{Ag}$ atoms was calculated with respect to their position in a perfect $f c c$ structure by using the GROMACS utility $g_{-} r m s$, which carries out least-square fitting the AgNP structure $\left(\tau_{2}\right)$ to its initial perfect structure $\left(\tau_{1}=0\right)(7)$.

$$
\operatorname{RMSD}\left(\tau_{1}, \tau_{2}\right)=\left[\frac{1}{N} \sum_{i=1}^{N}\left\|r_{i}\left(\tau_{1}\right)-r_{i}\left(\tau_{2}\right)\right\|^{2}\right]^{\frac{1}{2}}
$$

where $N$ and $r_{i}(\tau)$ are the number of Ag atoms, and the position Ag atom $i$ and its reference position at time $\tau[54,58]$. 
Fig. 2c shows the comparison of the RMSD behavior of $\mathrm{AgNP}_{1397}$ calculated by the using of the nonpolarizable (1) and polarizable (2) models, respectively. It can be noted that the introduction of the polarization effect resulted in only the small increase in $R M S D$ values from $0.0182 \pm 0.0006 \mathrm{~nm}$ up to $0.0189 \pm 0.0007 \mathrm{~nm}$, respectively.

a)

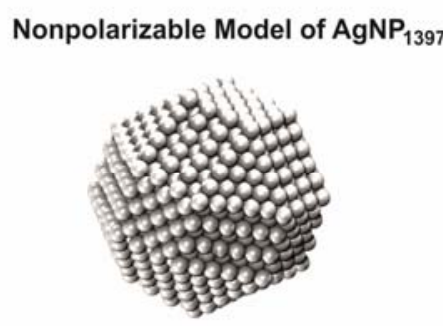

Polarizable Model of $\mathrm{AgNP}_{1397}$

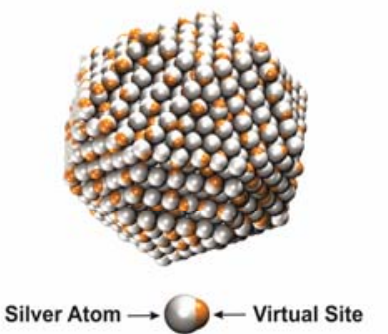

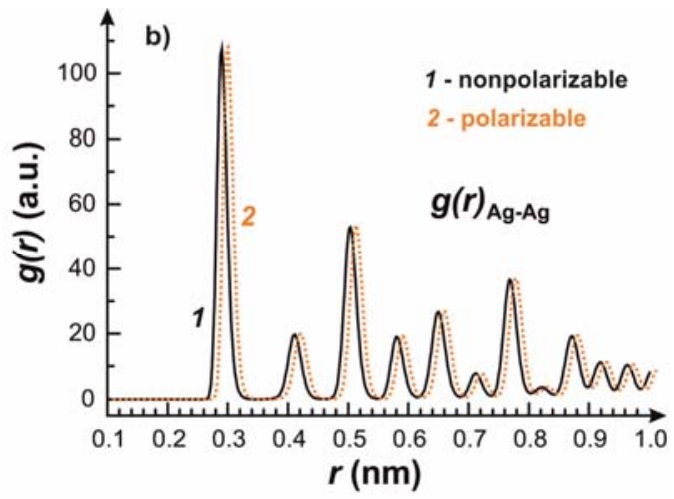

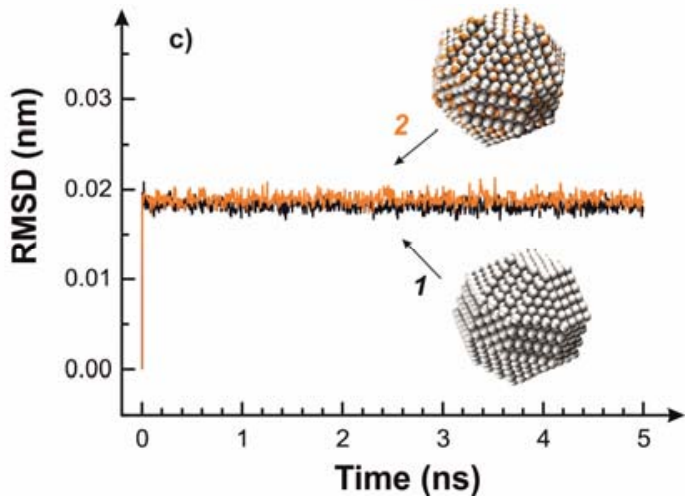

Figure 2. (a) Comparison of the structure of quasi-spherical $\mathrm{AgNP}_{1397}$ simulated in vacuum at $303 \mathrm{~K}$ by using the nonpolarizable (top) and polarizable (bottom) MD models. (b) A radial distribution function $\mathrm{g}(r)$ calculated over pairs of $\mathrm{Ag}-\mathrm{Ag}$ atoms in AgNPs. The RDF plots of $\mathrm{AgNP}_{1397}$ simulated with both nonpolarizable (1, solid) and polarizable (2, dotted) MD models reveal the very similar pattern, which is characteristic for the $f c c$ ordering of bulk crystalline silver. For clarity, the RDF plot derived from the polarizable model 2 was shifted up by $0.1 \mathrm{~nm}$. (c) The time traces of the root mean squares displacements $(R M S D)$ of the current position of silver atoms with respect to their position in the perfect $f c c$ crystalline lattice are shown in $\mathrm{AgNP}_{1397}$ calculated with the nonpolarizable (1) $(0.0182 \pm 0.0006 \mathrm{~nm})$ and polarizable $(0.0189 \pm 0.0007 \mathrm{~nm})(2)$ force fields.

\section{Silver Nanoparticles in Aqueous Solution}

On the next step, the performance of the polarizable FF was tested on AgNPs in the aqueous environment. For this purpose, $\mathrm{AgNP}_{1397}$ was placed in the cubic box of $6.5 \mathrm{~nm}$ size and solvated by 7880 SPC water molecules. Moreover, to study the effect of the polarization on adsorption of positive and negative ions on AgNP the additional MD simulations were carried out in the presence of $2 \mathrm{M}$ of $\mathrm{NaCl}$. Fig. $3 a$ shows the MD snapshot of the solvated $\mathrm{AgNP}_{1397}$ in the presence of $\mathrm{NaCl}$.

Adsorption of water molecules onto AgNP The adsorption of water molecules on AgNP was analyzed by calculating of the RDF between $\mathrm{Ag}$ and water oxygen atom $\mathrm{OW}$, respectively. The comparison of the RDF plots of $\mathrm{g}(r)_{\mathrm{Ag}-\mathrm{OW}}$ calculated for $\mathrm{AgNP}_{1397}$ modelled with the nonpolarizable and polarizable MD models shows very similar results (Fig. $3 b$ ). These findings suggest that the metal polarization does not perturb significantly the strength of the water adsorption.

Adsorption of ions onto AgNP. The further comparison of the nonpolarizable and polarizable FFs was performed by the analyzing of adsorption of ions onto the silver surface. Fig. $3 c$ shows the time evolution of the number of contacts between $\mathrm{AgNP}$ and $\mathrm{Na}^{+}$and $\mathrm{Cl}^{-}$ions, respectively. As can be seen, the striking difference was observed for the adsorption of positive $\mathrm{Na}^{+}$ions as compared to that of the negative $\mathrm{Cl}^{-}$ones. The use of the polarizable FF significantly favors the adsorptions of the $\mathrm{Na}^{+}$ions onto AgNP. Such influence of the salt is consistent with by the formation of the electrochemical double layer (EDL) between polarizable surface of silver atoms and counter ions. 
Structure of AgNP in solution. Finally, the performance of the new polarizable FF model for reproducing of the fcc structure of $\mathrm{AgNP}_{1397}$ was summarized by a series of MD simulations in vacuum and in the aqueous solution in the absence and in the presence of $\mathrm{NaCl}$ as compared in Fig. $3 d$ by the corresponding $R M S D$ time traces. It is seen that, upon MD simulations of $\mathrm{AgNP}_{1397}$ by the using the polarizable FF model, the RMSD values of silver atom positions were increased from $0.0189 \pm 0.0007 \mathrm{~nm}$ in vacuum up to $0.0215 \pm 0.0009$ (curve 3 ) $\mathrm{nm}$ in bulk water. However, only a small additional increase of up to $0.0218 \pm 0.0009$ (curve 4) was observed in the presence of $2 \mathrm{M} \mathrm{NaCl}$.

a)
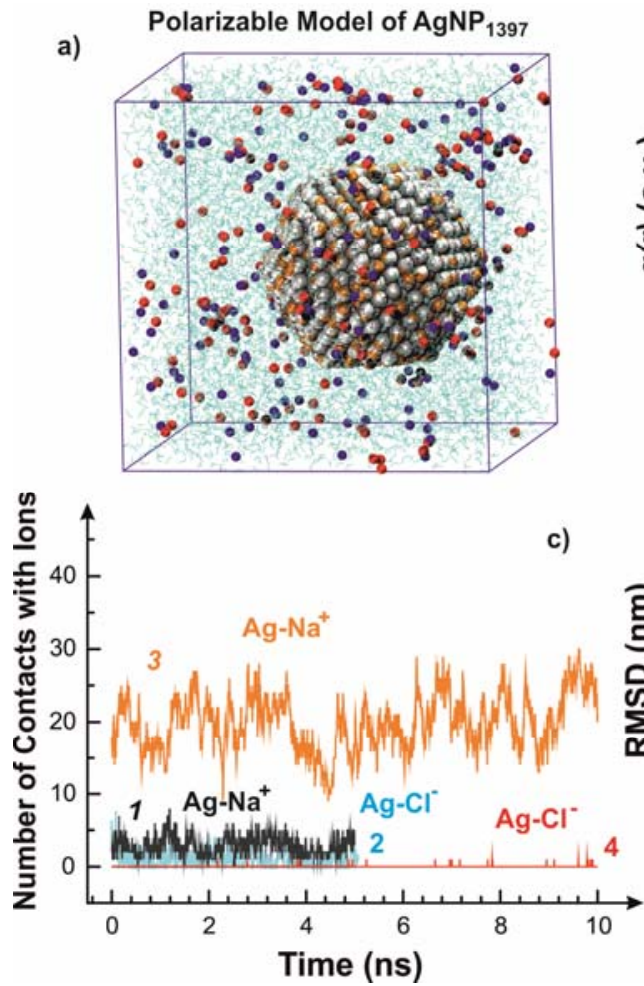

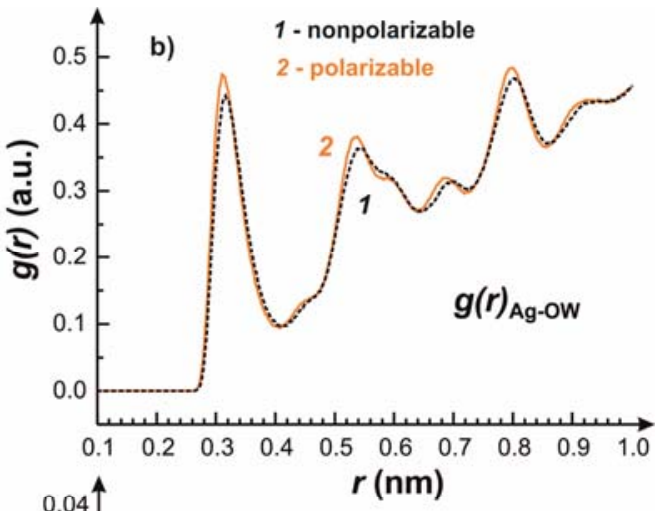

d)

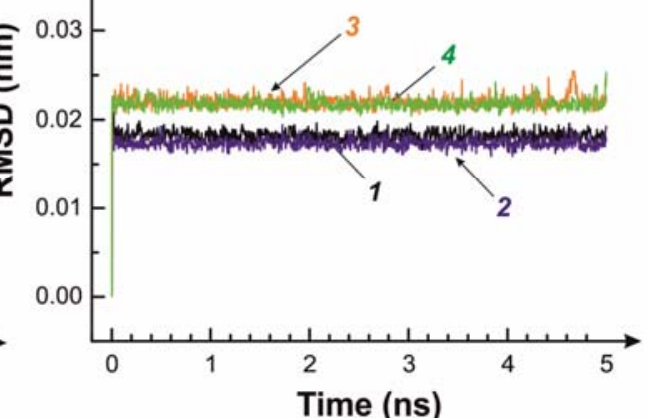

Figure 3. (a) A MD snapshot of the polarizable $\mathrm{AgNP}_{1397}$ solvated in the aqueous solution of $2 \mathrm{M}$ $\mathrm{NaCl}$ (red and blue balls). (b) Comparison of the RDF plots of $g(r)_{\mathrm{Ag}-\mathrm{OW}}$ calculated between the silver atom and water oxygen atoms $(\mathrm{OW})$ in the solvated $\mathrm{AgNP}_{1397}$ modelled with the nonpolarizable (1) and polarizable (2) MD models. (c) The time traces of the number of contacts $\mathrm{Na}^{+}$and $\mathrm{Cl}^{-}$ions with AgNP simulated with the nonpolarizable FF ( 1 and 2) and the polarizable FFs (3 and 4), respectively. (d) The RMSD time traces of the position of silver atoms in $\mathrm{AgNP}_{1397}$ calculated by using various approaches: (1) the nonpolarizable FF in vacuum, (2) the nonpolarizable FF in aqueous solution, (3) the polarizable FF in water, (4) the polarizable FF in water with added $2 \mathrm{M} \mathrm{NaCl}$.

\section{Adsorption Configurations of Water Molecules on Silver Surface}

The structure and properties of water molecules, adsorbed on well-defined metal surfaces, have been the subject of numerous experimental and theoretical investigations [59-63]. It these studies, the most favorable adsorption configurations of the water molecule on the silver surface were identified as shown in Fig. 4. The most stable structures were found to be atop configurations A and B, in which water is coordinated through the oxygen atom to the silver atom. The coordination through the hydrogen atom in configuration $\mathrm{C}$ was found to be unfavorable, so that this structure tends to rearrange to the above mentioned configurations $\mathrm{A}$ and $\mathrm{B}$, respectively.

The adsorption configuration of water molecules on the silver surface can therefore be considered as a crucial test and validation of the polarizable Ag model for reproducing of the well-known interaction characteristics of water molecules onto the silver surface. For simplicity, the silver surface was approximated with the three fixed (111) layers, for which the two sets, nonpolarizable and polarizable Ag models were applied. The adsorption dynamics and preferred structures of water molecules onto the silver slab were simulated at the NVT ensemble as shown in Fig. $5 a$. 


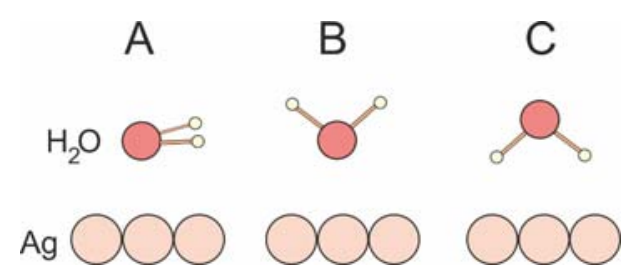

Figure 4. Schematic side view of the stable structures found for the water molecule on the silver surface adapted from [61].

Surprisingly, the analysis of the preferred adsorption configurations of water molecules on the silver surface modelled with the polarizable silver model revealed the large fraction of water molecules bound to the surface through atop configuration C (Insert in Fig. 5a). In contrast, such binding mode of water molecules was rarely observed for MD simulation with the nonpolarizable silver model. These findings were further confirmed by the RDF analysis of $g(r)_{\mathrm{Ag}-\mathrm{HW}}$ calculated between silver atoms and hydrogen atoms of water molecules (Fig. $5 b$ ), which revealed a small peak at $0.18 \mathrm{~nm}$ on the RDF curve (2) derived from the polarizable FF simulations.
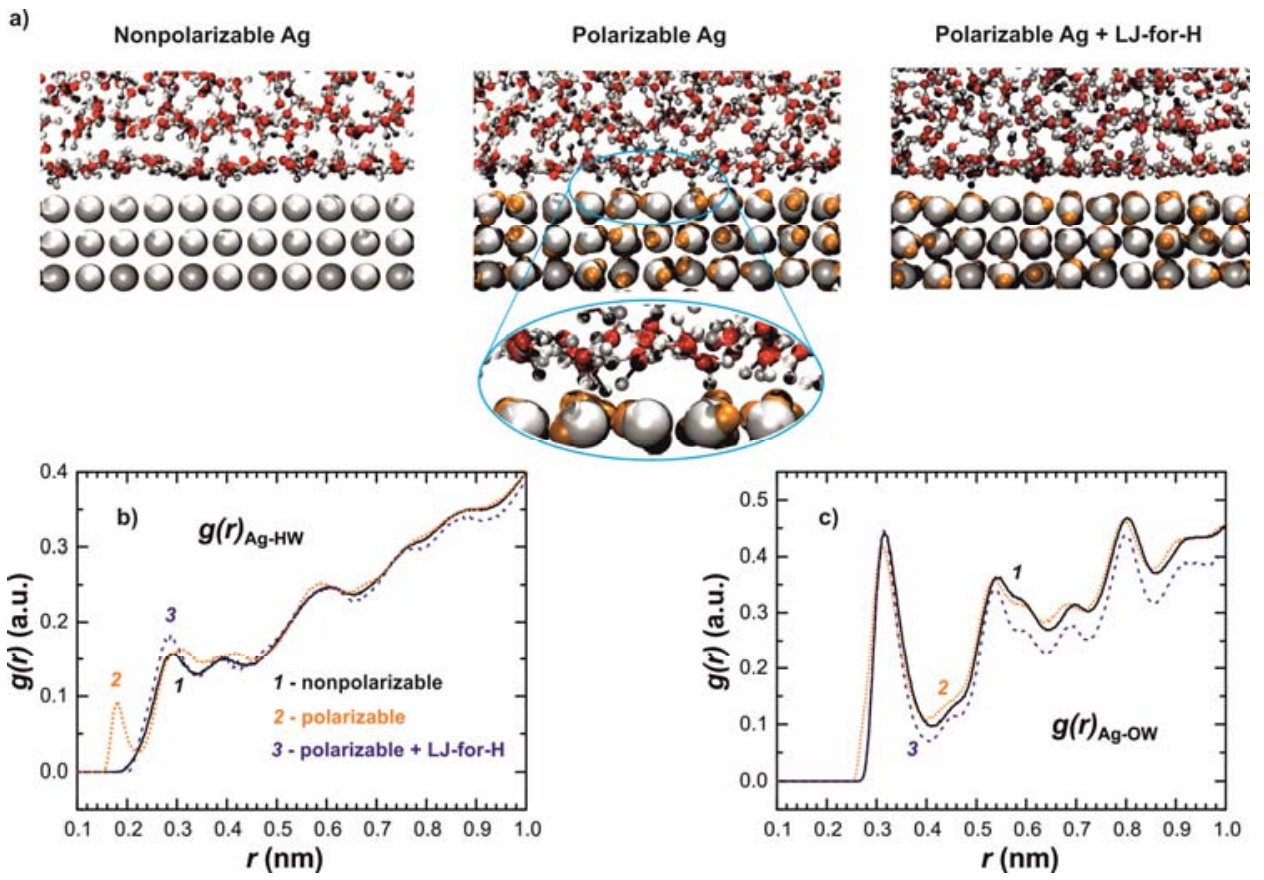

Figure 5. (a) Side-view snapshots of MD simulations of water molecules adsorbed on the silver surface as estimated with different FFs. Inset shows that the polarizable FF revealed that some fraction of adsorbed water molecules were found to be misoriented with one of its HW atoms pointing toward the silver surface. (b-c) Comparison of the RDF plots of $g(r)_{\mathrm{Ag}-\mathrm{HW}}(\boldsymbol{b})$ and $g(r)_{\mathrm{Ag}-\mathrm{OW}}(\boldsymbol{c})$ calculated between the silver atom and either hydrogen atoms (HW) or oxygen atoms (OW) of water molecules calculated with the nonpolarizable FF (1), polarizable FF (2), and polarizable FF with LJ-corrections on HW atoms.

Artificial orientation of hydrogen atoms of water molecules adsorbed onto the silver could be emerged as due to some overestimation of Coulomb attractions. This question was already discussed in literature and the following solution was suggested [42, 44]. To shift water hydrogens from the surface and make the computational model more physical, there is a necessity to compensate the Coulomb attraction by the Lennard-Jones nonbonded repulsion interaction between HW and silver atoms [50]. Therefore, the polarizable silver model was further modified by adding the LJ interactions between Ag atoms and hydrogen atoms (HW) of SPC waters. This modified polarizable model is referred to as Polarizable $\mathrm{Ag}+\mathrm{LJ}-$ for-H. The LJ interaction parameters Ag-HW were as following: $\sigma=0.30584 \mathrm{~nm}$ and $\varepsilon=0.74323 \mathrm{~kJ} / \mathrm{mol}$, respectively. As shown on the Fig. $5 a-c$ the water adsorption modelled with the modified polarizable silver model becomes very similar to physical expectations. The RDF curve (3) of $g(r)_{\mathrm{Ag}-\mathrm{HW}}$ shows no artificial peaks at $0.18 \mathrm{~nm}$ observed before. 
The comparison of the performance of the three different Ag models (Fig. 5) revealed that the implementation of the Ag polarization resulted in the limited influence on the adsorption behavior of water molecules near the Ag interface. The small changes in RDF peaks of $g(r)_{\mathrm{Ag}-\mathrm{OW}}$ in Fig. $5 \mathrm{c}$ demonstrated that the polarization effect of $\mathrm{Ag}$ has rather short-range effects, so that a minor contribution of the silver atom polarization was seen for adsorption of water molecules and ions form distant solvation shells. Recently, Menziani and coauthors [64] used MD simulations to study the adsorption of cytochrome $\mathrm{c}$ on various solvated silver surfaces by using the nonpolarizable and polarizable AgPCHARMM model [44] and they have also reported small effects of the implemented Ag polarization on binding modes of cytochrome $\mathrm{c}$.

a)

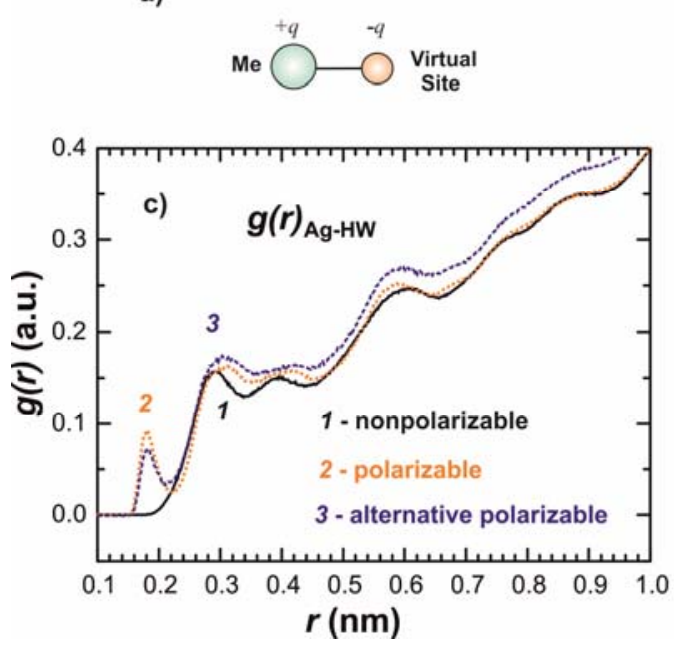

b)

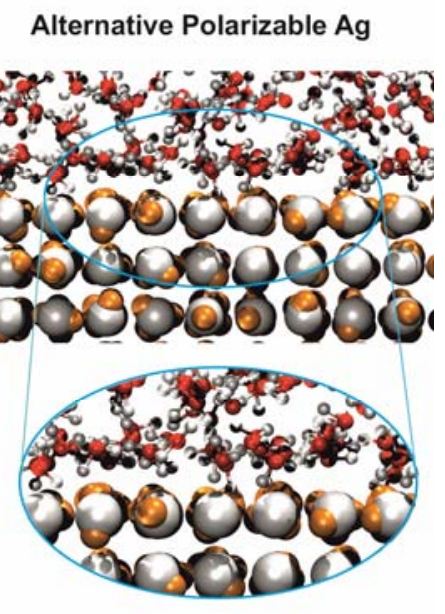

Figure 6. (a) Scheme of the alternative polarizable FF model. A Me atom is shown as a cyan ball and the virtual site is represented by an orange sphere. Both of them have their charges: $M e$ is charged positively $(+q)$ and the virtual site is charged negatively $(-q)$. (b) Side-view snapshots of MD simulations of water molecules adsorbed on the silver surface as estimated with the alternative polarizable FFs. Inset shows that some fraction of adsorbed water molecules were still found to be misoriented with one of its HW atoms pointing toward the silver surface. (c) Comparison of the RDF plots of $g(r)_{\mathrm{Ag}-\mathrm{HW}}$ calculated between the silver atom and hydrogen atoms $(\mathrm{HW})$ of water molecules calculated with the nonpolarizable FF (1), polarizable FF (2), and alternative polarizable FF (3), respectively.

Taking into account the importance of the proper characterization of water molecule orientation and dynamics at the aqueous/metal interfaces, more sophisticated approaches have also been suggested to mimic polarizability of bulk metal and surfaces $[50,65]$. Towards the proper treatment of the polarizability of metallic gold, Li and Ågren have developed the capacitance-polarizability force field for noble metal surfaces and nanoparticles by employing of different interacting potential functions for the metallic and nonmetallic components [66]. In their force field, the water-gold interaction was divided into three categories, each of which is described by different potential functions: the TIP3P model for water, the quantum Sutton-Chen potential for inner gold atoms, and the capacitance-polarizability interaction model for outermost gold atoms, represented by a modified LennardJones potential [66]. While this FF introduces extra complexity and hampers the practical flexibility and transferability for applications in different biomolecular systems, it provides some evidence that the surface of the aqueous gold nanoparticle may carry a negative charge, which is balanced by the positive charge in the second outermost gold layer.

Following the above arguments, we also verified the performance of the rigid rod polarizable model for AgNP by altering its positive and negative charges. The original rigid rod model was parameterized with a negative charge $-q$ assigned at metal atom $M e$, whereas a positive charge $+q$ fixed at a virtual site (Fig. 1). However, physical meaning of atomic polarizability is due to the displacement of electronic density under the influence of the external field, so that an alternative charging scheme of the rod model can also be valid, in which negative charge $-q$ is placed at a virtual site and positive charge $+q$ is fixed at metal atom $M e$, as shown in Fig. $6 a$. We carried out control MD simulations by using such alternative polarizable scheme. We found, however, that the charge reversing in the rigid 
rod model has a little effect on water adsorption at the silver surface. In particular, the structure of the first water layer and artificial water ordering were observed with MD simulations by using the original and reversed charging scheme of the rigid rod model, as seen in a snapshot and RDF plots of $g(r)_{\mathrm{Ag}-\mathrm{HW}}$ in Fig. 6b-c. Moreover, we also found that the charge reversing in the rigid rod model did not affect the adsorption of $\mathrm{Na}^{+}$and $\mathrm{Cl}^{-}$ions (not shown), which suggests that due to the short-range polarizability effects of the silver surface these ions prefer residing in bulk solution.

\section{Conclusions and Future Perspectives}

The polarization forces at inorganic/organic interface play an important role in the adsorption of water molecules, ions and organic ligands [31]. While the most of structural and thermodynamic properties of adsorbed species at silver surfaces are well accounted with the existing empirical force field, however, the accuracy of the simulations still depends on the suitability of the force field utilizing the pair-wise Lennard-Jones interaction models. Therefore, it has been shown that some certain aspects of the structure and dynamics of the first adsorbed water layer require the use of the softer Morse and Buckingham potentials [50]. Alternatively, it has been suggested that the existing force field may be upgraded by implementing various approaches, mimicking metal polarization effects [32].

In this work, we implemented and validated the polarizable FF parameters for Ag suitable for atomistic MD simulations of silver nanoparticles (AgNPs) and bulk-Ag/water interfaces. Our model is derived from the rigid rod model [40], in which induced charge polarization is represented by the displacement of a charge-carrying virtual site, attached rigidly to a polarizable $\mathrm{Ag}$ atom. We compared the performance of the classical nonpolarizable FF and the new polarizable model of Ag by the modeling of adsorption of water molecules and $\mathrm{NaCl}$ ions onto quasi-spherical $\mathrm{AgNP}$ and the flat crystalline (111) silver surface. The analysis of the radial distribution function of Ag-Ag atoms demonstrated that the introduction of the polarization effect had minor effects on the $f c c$ packing of silver atoms in both isolated and water solvated AgNPs, respectively. The implementation of the polarization effect led to some increase in attractive interactions between the silver surface and water molecules and $\mathrm{Na}^{+}$ions. As a crucial test of the developed polarizable model, the structure of adsorbed interfacial water molecules was analyzed. We found that the environment-induced polarization of the silver surface contributes significantly to the structure of the adsorbed interfacial water layer and plays an important role in the adsorption of positive ions. However, it was also demonstrated that the polarization effect of $\mathrm{Ag}$ is rather short-range, so that a minor contribution of the silver atom polarization was seen for adsorption of water molecules and ions from distant solvation shells [64]. Despite the short-range polarization effects, the proposed polarizable FF model for Ag can, however, have an important contribution for MD simulations of adsorption of charged organic ligands and polyelectrolytes due to Coulomb attractions. Moreover, the use of the polarizable Ag model might be promising for accurate estimation of the electrostatic potential at the silver surface. These studies are currently in progress in our team.

\section{Acknowledgements}

This work was performed using computational facilities of the joint computational cluster of SSI "Institute for Single Crystals" and Institute for Scintillation Materials of National Academy of Science of Ukraine incorporated into Ukrainian National Grid. The authors acknowledge Grant 0119U002532 of the Ministry of Education and Science of Ukraine.

\section{References}

1. Prasher P., Singh M., Mudila H. Silver nanoparticles as antimicrobial therapeutics: Current perspectives and future challenges. 3 Biotech 2018, 8 (10), art. no. 411.

2. Stamplecoskie K. Silver nanoparticles: From bulk material to colloidal nanoparticles. In Silver nanoparticle applications: In the fabrication and design of medical and biosensing devices, Alarcon, E. I.; Griffith, M.; Udekwu, K. I., Eds. Springer International Publishing: Cham, 2015; pp 1-12.

3. Prabhu S., Poulose E. K. Silver nanoparticles: Mechanism of antimicrobial action, synthesis, medical applications, and toxicity effects. International Nano Letters 2012, 2 (1), art. no. 32. 
4. Franci G., Falanga A., Galdiero S., Palomba L., Rai M., Morelli G., Galdiero M. Silver nanoparticles as potential antibacterial agents. Molecules 2015, 20 (5), 8856-8874.

5. Tian P. Molecular dynamics simulations of nanoparticles. Ann Rep Sect C: Phys. Chem. 2008, 104 142-164.

6. Konuk M., Durukanoglu S. Shape-controlled growth of metal nanoparticles: An atomistic view. Phys. Chem. Chem. Phys. 2016, 18 (3), 1876-1885.

7. Fichthorn K. A., Balankura T., Qi X. Multi-scale theory and simulation of shape-selective nanocrystal growth. CrystEngComm 2016, 18 (29), 5410-5417.

8. Blazhynska M. M., Kyrychenko A., Kalugin O. N. Molecular dynamics simulation of the sizedependent morphological stability of cubic shape silver nanoparticles. Mol. Simul. 2018, 44 (12), 981-991.

9. Blazhynska M. M., Kyrychenko A. V., Kalugin O. N. Molecular dynamics simulations of silver nanoparticles of cubic and bipyramidal shape. Kharkov University Bulletin. Chemical Series. 2017, 29 (52), 23-30.

10. Fichthorn K. A. Atomic-scale theory and simulations for colloidal metal nanocrystal growth. J. Chem. Eng. Data 2014, 59 (10), 3113-3119.

11. Martin L., Bilek M. M., Weiss A. S., Kuyucak S. Force fields for simulating the interaction of surfaces with biological molecules. Interface Focus 2016, 6 (1), art. no. 20150045.

12. Monti S., Barcaro G., Sementa L., Carravetta V., Ågren H. Characterization of the adsorption dynamics of trisodium citrate on gold in water solution. RSC Adv. 2017, 7 (78), 49655-49663.

13. Kyrychenko A., Karpushina G. V., Bogatyrenko S. I., Kryshtal A. P., Doroshenko A. O. Preparation, structure, and a coarse-grained molecular dynamics model for dodecanethiolstabilized gold nanoparticles. Comput. Theor. Chem. 2011, 977 (1-3), 34-39.

14. Henz B. J., Chung P. W., Andzelm J. W., Chantawansri T. L., Lenhart J. L., Beyer F. L. Determination of binding energy and solubility parameters for functionalized gold nanoparticles by molecular dynamics simulation. Langmuir 2011, 27 (12), 7836-7842.

15. Kyrychenko A., Karpushina G. V., Svechkarev D., Kolodezny D., Bogatyrenko S. I., Kryshtal A. P., Doroshenko A. O. Fluorescence probing of thiol-functionalized gold nanoparticles: Is alkylthiol coating of a nanoparticle as hydrophobic as expected? J. Phys. Chem. C 2012, 116 (39), 21059-21068.

16. Sridhar D. B., Gupta R., Rai B. Effect of surface coverage and chemistry on self-assembly of monolayer protected gold nanoparticles: A molecular dynamics simulation study. Phys. Chem. Chem. Phys. 2018, 20 (40), 25883-25891.

17. Pohjolainen E., Chen X., Malola S., Groenhof G., Häkkinen H. A unified AMBER-compatible molecular mechanics force field for thiolate-protected gold nanoclusters. J. Chem. Theory Comput. 2016, 12 (3), 1342-1350.

18. Slavgorodska M. V., Kyrychenko A. V. Binding preference of $\alpha$-cyclodextrin onto gold nanoparticles. Nanosistemi, Nanomateriali, Nanotehnologii 2019, 17 (1), 133-144.

19. Kyrychenko A., Korsun O. M., Gubin I. I., Kovalenko S. M., Kalugin O. N. Atomistic simulations of coating of silver nanoparticles with poly(vinylpyrrolidone) oligomers: Effect of oligomer chain length. J. Phys. Chem. C 2015, 119 (14), 7888-7899.

20. Milano G., Santangelo G., Ragone F., Cavallo L., Di Matteo A. Gold nanoparticle/polymer interfaces: All atom structures from molecular dynamics simulations. J. Phys. Chem. C 2011, 115 (31), 15154-15163.

21. Shen Z., Nieh M.-P., Li Y. Decorating nanoparticle surface for targeted drug delivery: Opportunities and challenges. Polymers 2016, 8 (3), art. no. 83.

22. Hwang J., Shim Y., Yoon S.-M., Lee S. H., Park S.-H. Influence of polyvinylpyrrolidone (PVP) capping layer on silver nanowire networks: Theoretical and experimental studies. RSC Adv. 2016, 6 (37), 30972-30977.

23. Balankura T., Qi X., Zhou Y., Fichthorn K. A. Predicting kinetic nanocrystal shapes through multi-scale theory and simulation: Polyvinylpyrrolidone-mediated growth of $\mathrm{Ag}$ nanocrystals. J. Chem. Phys. 2016, 145 (14), art. no. 144106.

24. Kyrychenko A., Blazhynska M. M., Slavgorodska M. V., Kalugin O. N. Stimuli-responsive adsorption of poly(acrylic acid) onto silver nanoparticles: Role of polymer chain length and degree of ionization. J. Mol. Liq. 2019, 276, 243-254. 
25. Ethier J. G., Hall L. M. Modeling individual and pairs of adsorbed polymer-grafted nanoparticles: Structure and entanglements. Soft Matter 2018, 14 (4), 643-652.

26. Kumar S. K., Ganesan V., Riggleman R. A. Perspective: Outstanding theoretical questions in polymer-nanoparticle hybrids. J Chem. Phys. 2017, 147 (2), art. no. 020901.

27. Shao Q., Hall C. K. Allosteric effects of gold nanoparticles on human serum albumin. Nanoscale 2017, 9 (1), 380-390.

28. Kyrychenko A. NANOGOLD decorated by pHLIP peptide: Comparative force field study. Phys. Chem. Chem. Phys. 2015, 17 (19), 12648-12660.

29. Ramezani-Dakhel H., Bedford N. M., Woehl T. J., Knecht M. R., Naik R. R., Heinz H. Nature of peptide wrapping onto metal nanoparticle catalysts and driving forces for size control. Nanoscale 2017, 9 (24), 8401-8409.

30. Colangelo E., Chen Q., Davidson A. M., Paramelle D., Sullivan M. B., Volk M., Lévy R. Computational and experimental investigation of the structure of peptide monolayers on gold nanoparticles. Langmuir 2017, 33 (1), 438-449.

31. Heinz H., Jha K. C., Luettmer-Strathmann J., Farmer B. L., Naik R. R. Polarization at metalbiomolecular interfaces in solution. J. Royal Soc. Interf. 2011, 8 (55), 220-232.

32. Lemkul J. A., Huang J., Roux B., MacKerell A. D. An empirical polarizable force field based on the classical drude oscillator model: Development history and recent applications. Chem. Rev. 2016, $116(9), 4983-5013$.

33. Ozboyaci M., Kokh D. B., Corni S., Wade R. C. Modeling and simulation of protein-surface interactions: Achievements and challenges. Quant. Rev. Biophys. 2016, 49, art. no. e4 (87 pages).

34. Makarucha A., Todorova N., Yarovsky I. Nanomaterials in biological environment: A review of computer modelling studies. Europ. Biophys. J. 2011, 40 (2), 103-115.

35. Charchar P., Christofferson A. J., Todorova N., Yarovsky I. Understanding and designing the gold-bio interface: Insights from simulations. Small 2016, 12 (18), 2395-2418.

36. Heinz H., Ramezani-Dakhel H. Simulations of inorganic-bioorganic interfaces to discover new materials: Insights, comparisons to experiment, challenges, and opportunities. Chem. Soc. Rev. 2016, 45 (2), 412-448.

37. Kyrychenko A., Pasko D. A., Kalugin O. N. Poly(vinyl alcohol) as a water protecting agent for silver nanoparticles: The role of polymer size and structure. Phys. Chem. Chem. Phys. 2017, 19 (13), 8742-8756.

38. Heinz H., Vaia R. A., Farmer B. L., Naik R. R. Accurate simulation of surfaces and interfaces of face-centered cubic metals using 12-6 and 9-6 Lennard-Jones potentials. J. Phys. Chem. C 2008, 112 (44), 17281-17290.

39. Předota M., Machesky M. L., Wesolowski D. J. Molecular origins of the Zeta potential. Langmuir 2016, 32 (40), 10189-10198.

40. Iori F., Corni S. Including image charge effects in the molecular dynamics simulations of molecules on metal surfaces. J. Comput. Chem. 2008, 29 (10), 1656-1666.

41. Iori F., Di Felice R., Molinari E., Corni S. GolP: An atomistic force-field to describe the interaction of proteins with $\mathrm{Au}(111)$ surfaces in water. J. Comput. Chem. 2009, 30 (9), 1465-1476.

42. Wright L. B., Rodger P. M., Corni S., Walsh T. R. GolP-CHARMM: First-principles based force fields for the interaction of proteins with $\mathrm{Au}(111)$ and $\mathrm{Au}(100)$. J. Chem. Theory Comput. 2013, 9 (3), 1616-1630.

43. Wright L. B., Rodger P. M., Walsh T. R., Corni S. First-principles-based force field for the interaction of proteins with $\mathrm{Au}(100)(5 \times 1)$ : An extension of GolP-CHARMM. J. Phys. Chem. C 2013, 117 (46), 24292-24306.

44. Hughes Z. E., Wright L. B., Walsh T. R. Biomolecular adsorption at aqueous silver interfaces: First-principles calculations, polarizable force-field simulations, and comparisons with gold. Langmuir 2013, 29 (43), 13217-13229.

45. Wright L. B., Rodger P. M., Walsh T. R. Structure and properties of citrate overlayers adsorbed at the aqueous $\mathrm{Au}(111)$ interface. Langmuir 2014, 30 (50), 15171-15180.

46. Hughes Z. E., Walsh T. R. Non-covalent adsorption of amino acid analogues on noble-metal nanoparticles: Influence of edges and vertices. Phys. Chem. Chem. Phys. 2016, 18 (26), 17525-17533. 
47. Hughes Z. E., Walsh T. R. Distinct differences in peptide adsorption on palladium and gold: Introducing a polarizable model for Pd(111). J. Phys. Chem. C 2018, 122 (34), 19625-19638.

48. Perfilieva O. A., Pyshnyi D. V., Lomzov A. A. Molecular dynamics simulation of polarizable gold nanoparticles interacting with sodium citrate. J. Chem. Theory Comput. 2019, 15 (2), 1278-1292.

49. Heinz H., Lin T.-J., Kishore Mishra R., Emami F. S. Thermodynamically consistent force fields for the assembly of inorganic, organic, and biological nanostructures: The interface force field. Langmuir 2013, 29 (6), 1754-1765.

50. Berg A., Peter C., Johnston K. Evaluation and optimization of interface force fields for water on gold surfaces. J. Chem. Theory Comput. 2017, 13 (11), 5610-5623.

51. Hermans J., Berendsen H. J. C., Van Gunsteren W. F., Postma J. P. M. A consistent empirical potential for water-protein interactions. Biopolymers 1984, 23 (8), 1513-1518.

52. Schuler L. D., Daura X., van Gunsteren W. F. An improved Gromos96 force field for aliphatic hydrocarbons in the condensed phase. J. Comput. Chem. 2001, 22 (11), 1205-1218.

53. Berendsen H. J. C., Postma J. P. M., van Gunsteren W. F., DiNola A., Haak J. R. Molecular dynamics with coupling to an external bath. J. Chem. Phys. 1984, 81 (8), 3684-3690.

54. Van Der Spoel D., Lindahl E., Hess B., Groenhof G., Mark A. E., Berendsen H. J. C. Gromacs: Fast, flexible, and free. J. Comput. Chem. 2005, 26 (16), 1701-1718.

55. Humphrey W., Dalke A., Schulten K. VMD: Visual molecular dynamics. J. Mol. Graphics 1996, $14(1), 33-38$.

56. Tian Z.-A., Liu R.-S., Liu H.-R., Zheng C.-X., Hou Z.-Y., Peng P. Molecular dynamics simulation for cooling rate dependence of solidification microstructures of silver. J. Non. Cryst. Solids 2008, 354 (31), 3705-3712.

57. Medrano L. R., Landauro C. V. Influence of chemical disorder on the electronic level spacing distribution of the nanoparticle: A tight-binding study. Phys. B: Condensed Matter 2013, 412, 122-125.

58. Van Der Spoel D., Lindahl E., Hess B., van Buuren A. R., Apol E., Meulenhoff P. J., Tieleman D. P., Sijbers A. L. T. M., Feenstra K. A., van Drunen R., Berendsen H. J. C. Gromacs user manual version 4.5.4. www.gromacs.org: 2010; $\mathrm{p} 372$.

59. Carrasco J., Hodgson A., Michaelides A. A molecular perspective of water at metal interfaces. Nat. Mater. 2012, 11, art. no. 667.

60. Izvekov S., Voth G. A. Ab initio molecular dynamics simulation of the Ag(111)-water interface. J. Chem. Phys. 2001, 115 (15), 7196-7206.

61. Ranea V. A., Michaelides A., Ramírez R., Vergés J. A., de Andres P. L., King D. A. Density functional theory study of the interaction of monomeric water with the $\operatorname{Ag}\{111\}$ surface. Phys. Rev. B 2004, 69 (20), art. no. 205411.

62. Meng S., Wang E. G., Gao S. Water adsorption on metal surfaces: A general picture from density functional theory studies. Phys. Rev. B 2004, 69 (19), art. no. 195404.

63. Groß A., Gossenberger F., Lin X., Naderian M., Sakong S., Roman T. Water structures at metal electrodes studied by ab initio molecular dynamics simulations. J. Electrochem. Soc. 2014, 161 (8), E3015-E3020.

64. Tavanti F., Pedone A., Matteini P., Menziani M. C. Computational insight into the interaction of cytochrome c with wet and PVP-coated Ag surfaces. J. Phys. Chem. B 2017, 121 (41), 9532-9540.

65. Cicero G., Calzolari A., Corni S., Catellani A. Anomalous wetting layer at the Au(111) surface. J. Phys. Chem. Lett. 2011, 2 (20), 2582-2586.

66. Li X., Ågren H. Molecular dynamics simulations using a capacitance-polarizability force field. J. Phys. Chem. C 2015, 119 (33), 19430-19437. 
М.М. Блажинская, А.В. Кириченко, О.Н. Калугин. Поляризационное силовое поле для молекулярнодинамического моделирования наночастиц серебра.

Харьковский национальный университет имени В.Н. Каразина, химический фракультет, пл. Свободы, 4, Харьков, 61022, Украина

При контакте металлических поверхностей серебра с водой, ионами и органическими лигандами возникают индуцированные заряды, которые приводят к поляризации. Поляризационные силы играют важную роль в неорганических и органических межсразных границах и влияют на другие нековалентные поверхностные взаимодействия. Несмотря на важность этих взаимодействий, до сих пор было сложно реализовать такие поляризационные эфффекты в классическом молекулярно-динамическом моделировании (МД). В первую очередь, в данной статье представлен обзор двух популярных поляризационных моделей, таких как модель осциллятора Друде и модель жесткого стержня, которые используются для описания поляризации объемных металлов. Во-вторых, нами разработано поляризационное силовое поле (СП) для атома серебра на основе модели жесткого стержня, которое впоследствии было адаптировано к атомистическому моделированию наночастиц серебра (AgNP), состоящих из 1397 атомов. В предложенной модели зарядово-индуцированная поляризация представлена смещением виртуального сайта с зарядом, жестко прикрепленного к обычному атому Ag. Для исследования роли поляризации мы сравнили данные, полученные с использованием классического неполяризованного СП и новой поляризационной модели в МД моделировании адсорбции воды и ионов на квазиссрерической наночастинце AgNP и плоской кристаллической поверхности серебра. Анализ функции радиального распределения атомов Ag-Ag продемонстрировал, что внедрение поляризационного эффекта незначительно влияет на упаковку атомов серебра в гранецентрированную кубическую решетку AgNP, изолированную в вакууме, и AgNP, сольватированную в воде. Показано, что поляризационное силовое поле вызывает некоторое усиление взаимодействия между поверхностью серебра и молекулами воды, и ионами $\mathrm{Na}^{+}$. В качестве решающего теста разработанной поляризационной модели, нами была проанализирована структура слоя адсорбированных межфазных молекул воды. Наши данные свидетельствуют о том, что обусловлена окружающей средой поляризация поверхности серебра в значительной степени влияет на структуру адсорбированных межфазных слоев воды, а также она играет важную роль в адсорбции положительно заряженных ионов. Однако было также установлено, что эффект поляризации является достаточно короткодействующим, поэтому наблюдается незначительный вклад поляризации серебра в адсорбцию молекул воды, и ионов из отдаленных сольватных оболочек.

Ключевые слова: серебро, наночастица, гранецентрированная кубическая решетка, ГЦК, поляризационная модель, осциллятор Друде, молекулярно-динамическое моделирование.

М.М. Блажинська, О.В. Кириченко, О.М. Калугін. Полярізаційне силове поле для молекулярнодинамічного моделювання наночастинок срібла.

Харківський національний університет імені В.Н. Каразіна, хімічний фракультет, майдан Свободи, 4, Харків, 61022, Україна

При контакті металевих поверхонь срібла з водою, іонами та органічними лігандами виникають індуковані заряди, що призводять до поляризації. Поляризаційні сили відіграють важливу роль на неорганічних та органічних міжфазних границях і впливають на інші невалентні поверхневі взаємодії. Незважаючи на важливість цих взаємодій, до сих пір було складно реалізувати такі поляризаційні ефекти для класичного молекулярнодинамічного моделювання (МД). В першу чергу, у даній статті наведено огляд двох популярних поляризаційних моделей, такі як модель осцилятора Друде і модель жорсткого стрижня, які використовуються для відтворення поляризації об'ємних металів. По-друге, ми застосували модель жорсткого стрижня до поляризаційного силового поля (СП) для атома срібла, яке було згодом адаптовано для атомістичного моделювання наночастинок срібла (AgNP), що складаються з 1397 атомів. У нашій моделі індукована поляризація заряду представлена зміщенням віртуального сайту з зарядом, жорстко прикріпленого до звичайного атома $\mathrm{Ag}$. Для дослідження ролі поляризації ми порівняли дані, отриманні з використанням класичного неполяризаційного СП та нової поляризаційної моделі, в МД моделюванні адсорбції води та іонів на квазісфреричній наночастинці AgNP та плоскій кристалічній поверхні срібла. Аналіз функції радіального розподілу атомів Ag-Ag продемонстрував, що впровадження поляризаційного ефекту незначно впливає на гранецентровану кубічну ґратку атомів срібла наночастинки, що ізольована в вакуумі, та AgNP, сольватованої у воді. Ми виявили, що поляризаційне силове поле викликає деяке посилення взаємодій між поверхнею срібла і молекулами води, та іонами $\mathrm{Na}^{+}$. В якості вирішального тесту розробленої поляризаційної моделі, нами була проаналізована структура шару адсорбованих міжфазних молекул води. Наші дані свідчать про те, що обумовлена навколишнім середовищем поляризація срібної поверхні значною мірою впливає на структуру адсорбованих міжфазних шарів води, а також вона відіграє важливу роль в адсорбції позитивно заряджених іонів. Однак було також встановлено, що ефект поляризації є досить короткодіючим, тому спостерігається незначний внесок поляризації срібла в адсорбцію молекул води, і іонів із віддалених сольватних оболонок.

Ключові слова: срібло, наночастинки, гранецентрована кубічна ѓратка, ГЦК, поляризаційна модель, осцилятор Друде, молекулярно-динамічне моделювання.

Kharkiv University Bulletin. Chemical Series. Issue 32 (55), 2019 